\title{
Arteficiális dermatitis
}

\section{Dermatitis artefacta}

\author{
MARIE ISOLDE JOURA, KOSZORÚ KAMILLA DR., SÁRDY MIKLÓS DR. \\ Semmelweis Egyetem, Általános Orvostudományi Kar, \\ Bör-, Nemikórtani és Bőronkológiai Klinika, Budapest
}

\section{ÖSSZEFOGLALÁS}

Az arteficiális dermatitis egy pszichodermatológiai probléma, mely elsösorban nöket, serdülöket, pszichiátriai betegeket, vagy személyiségzavarban szenvedöket érint. A betegek különféle módokon okoznak maguknak sérülést vagy produkálnak látható börtünetet. A jellegzetes klinikai képet mutató eltérések mellett általában fellelhetö a társuló pszichés zavar, de a dermatitis organikus okait minden esetben ki kell zárni. A terápia során fontos törekedni a pszichodermatológiai szemléletre. Elengedhetetlen, hogy a börtünetek kezelése mellett a beteg pszichés támogatásban is részesüljön, szükség esetén megfelelö szakemberek bevonásával. A szerzök egy fiatal nöbeteg esetét ismertetik, aki tartós pszichés stressz következtében festékkel okozott magán börtünetet.

\section{Kulcsszavak:}

$$
\begin{gathered}
\text { dermatitis artefacta - színlelt betegség - } \\
\text { önkárosító magatartás - önsértés }
\end{gathered}
$$

\section{SUMMARY}

Dermatitis artefacta is a psychocutaneous illness that affects especiallywomen, adolescentsandpatientswithanunderlying psychiatric illness or personality disorder (especially borderline), as well as patients with external stress. Patients inflict injuries in various ways, most often mechanically. The clinical signs are characteristic and are usually combined with psychological disorders. In the differential diagnosis organic causes of dermatitis must be ruled out. The therapy should be carried out by a psychodermatological team to treat both the skin lesions and the patient's psyche. We report on a patient with dermatitis artefacta who produced skin lesions using dye-stuff because of psychological stress.

\section{Key words:}

\author{
factitious disorders - malingering - \\ self-injurious behavior-self-inflicted \\ dermatitis - factitial dermatitis
}

$\mathrm{Az}$ arteficiális dermatitis egy elsősorban nőket és serdülőkorúakat érintő probléma, mely során a betegek szándékosan, gyakran önsértéssel saját bőrükön idéznek elö látható tüneteket. A háttérben legtöbbször pszichiátriai betegség vagy fokozott stressz áll (1). A klinikai képre jellemző, hogy az elváltozások az ép bőrtől élesen elhatárolódnak és szokatlan, gyakran szabályos geometriai mintázatot mutatnak (2). További jellegzetesség, hogy a tünetek a beteg által könnyen elérhető bőrterületre lokalizálódnak (3). Az önsértés történhet pl. mechanikus, termikus, kémiai, vagy infektív behatással. Leggyakoribb a mechanikai ártalom, pl. a bőr karcolása vagy intenzív dörzsölése, mely hólyagképződéshez vezethet (4). A szövettani lelet változatos, a sokféle kialakulási mechanizmus miatt nincs általánosan érvényes eltérés (5). Előfordul pl. hólyagképződés, a dermális kollagénrostok destrukciója vagy az epidermisben többmagvú, esetleg elongált sejtmaggal rendelkező keratinocyták jelenléte Levelező szerző: Sárdy Miklós dr. e-mail cím: titkarsag.bor@med.semmelweis-univ.hu
(4). Leggyakrabban epidermális nekrózis és aspecifikus dermális gyulladás látható. Lehetséges továbbá szubepidermális hólyagképződés pl. elektromos égés következtében, illetve különféle anyagok injekciója folytán kialakulhatnak dermális vagy szubkután idegentest granulomák is (5).

\section{Esetismertetés}

A 18 éves nőbeteg édesapja kíséretében jelentkezett ambulanciánkon a jobb lábfején hónapok óta fennálló erythemás, progrediáló bőrtünetek miatt. Az anamnézis alapján korábban hólyagok is kialakultak, melyek mindig a jobb lábhát distalis részén jelentkeztek, végül spontán regrediáltak (1. ábra). A jelenlegi bőrelváltozást megelőzően a tünetek teljes remisszióban voltak. A beteget ezen panaszokkal korábban gyermekbörgyógyászaton is vizsgálták infekció és hólyagos autoimmun betegségek irányában, melyek közül egyik sem igazolódott. 


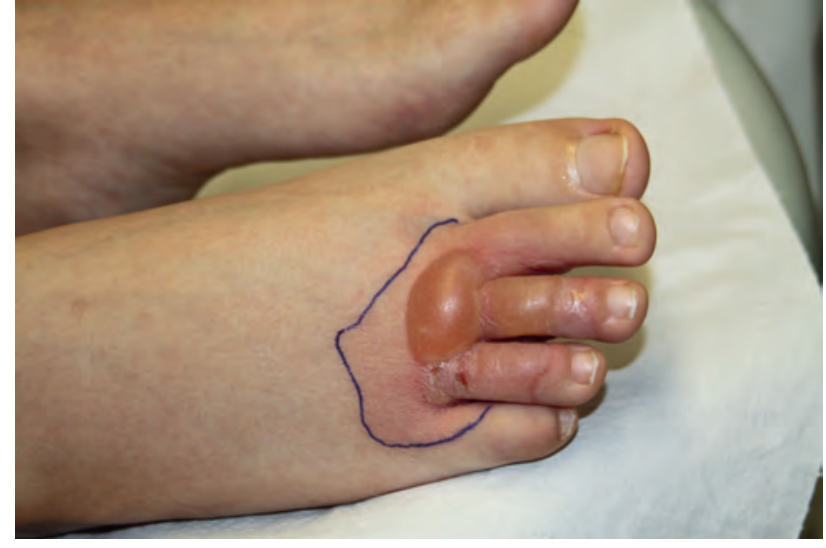

1. ábra

Egy korábbi fényképen hólyagképződés látható a jobb lábhát distalis részén.

\section{Klinikai kép, diagnosztika}

A jobb lábháton a lábhát közepétől distal felé egy élesen határolt, vörös folt volt látható (2. ábra). A lábfej bőre hűvös volt, ödéma és infiltráció nem volt tapintható. Dermatoszkóppal a bőr redőiben fénylö vörös szín látszott, míg a vonalak közti bőrfelszín megkímélt maradt (3. ábra). Tágult érképletek nem mutatkoztak. A lábujjközökben szintén látható volt a vörös elszínezödés, melynek megjelenése egy hígan folyó festék csorgásának nyomára emlékeztetett.

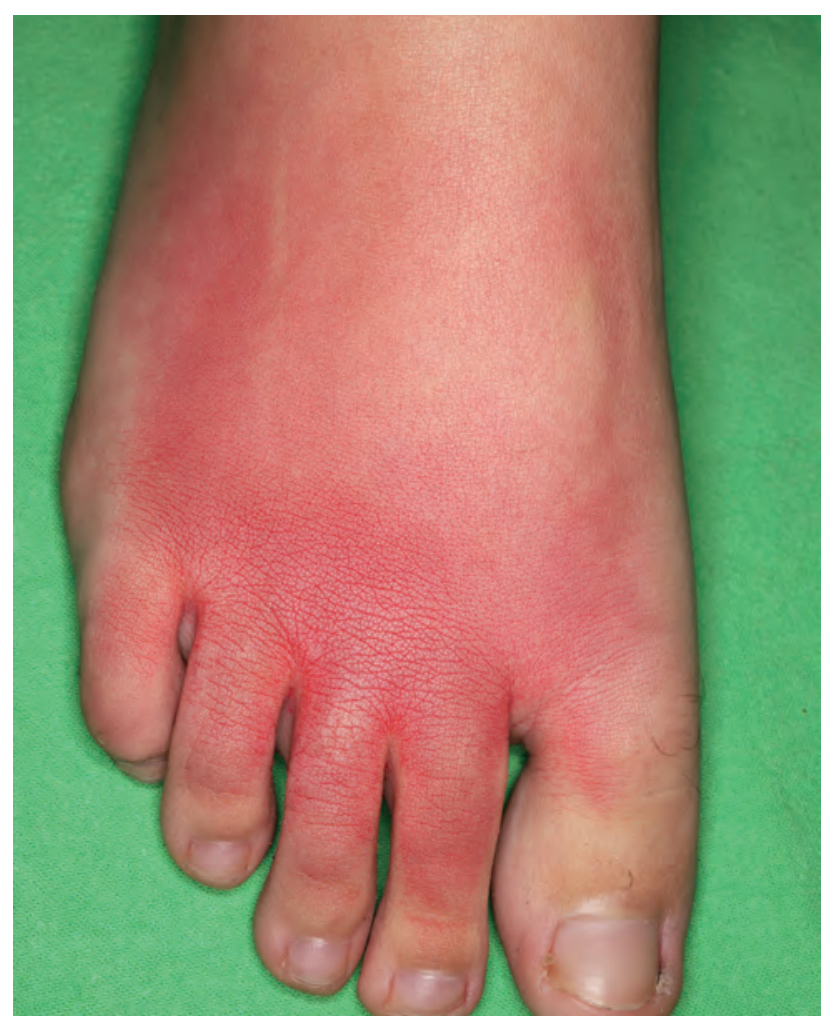

2. ábra

Az ambulanciánkon észlelt klinikai kép: a jobb lábhát distalis részén, részben a lábujjak közé is beterjedő vörös folt.

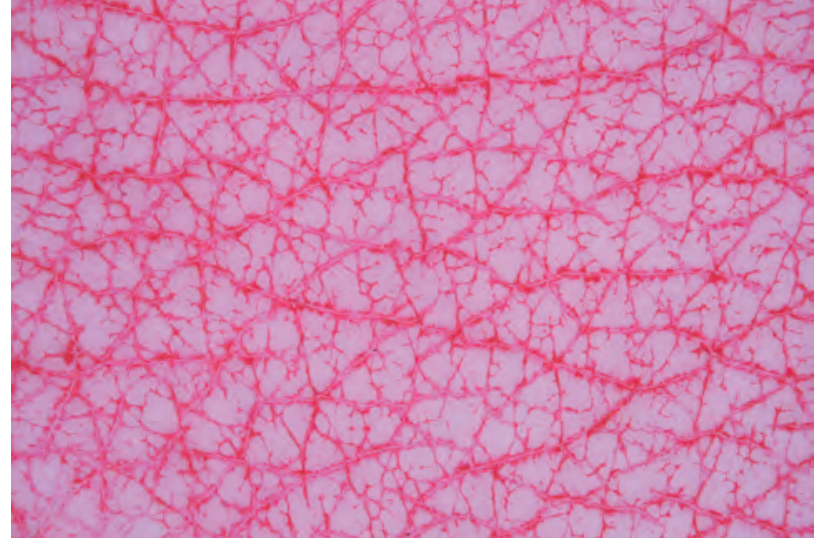

3. ábra

Dermatoszkópos felvételen látható a bőr redőire korlátozódó vörös szín és a vonalak közti bőrfelszín megkíméltsége

\section{Diagnózis, terápia}

A klinikai kép alapján megállapítható volt, hogy a beteg piros festéket vitt fel a jobb lábfejére. A részletes anamnézisfelvétel megerősítette az arteficiális dermatitis diagnózisát. A beteg édesapja elmondta, hogy lánya a szülök válása óta bipoláris zavarban szenvedö édesanyjával élt, aki mellett évekig mindennapos konfliktushelyzetben és állandó pszichés terhelés alatt állt. A nőbeteg 18. születésnapja óta él édesapjával, akivel az elmúlt rövid időszakban három különböző bőrgyógyászati rendelésen is jártak a fent említett tünetek miatt. Az arteficiális dermatitis egyik alkalommal sem került felismerésre. Ambulanciánkon a diagnózis felállítását követően az édesapát tájékoztattuk a diagnózisról és a betegséggel kapcsolatos tudnivalókról. Felvilágosítottuk, hogy ebben a szituációban legfontosabb egy stabil, támogató, szeretetteljes környezet biztosítása és a lánya önbizalmának megerősítése. Javasoltuk az elváltozás fedését és a festékkel való kontaktus kerülését.

A beteg és édesapja azóta nem jelentkeztek ambulanciánkon. Az édesapa telefonos konzultáció során megerősítette, hogy a bőrgyógyászati probléma megoldódott, látogatásuk óta új tünetet nem észlelt lányán.

\section{Megbeszélés}

A „dermatitis artefacta“ és „factitial dermatitis“ kulcsszavakra keresve a PubMed adatbázisa 313 találatot adott eredményül 2020. június 10-én. A publikációk viszonylag alacsony száma arra enged következtetni, hogy a betegség alulreprezentált az irodalomban. Esetünk is szemléletes példa arra, hogy a diagnózis felállítása nem mindig egyszerü, így az arteficiális dermatitis feltehetően sokszor nem kerül felismerésre (3). A fiatal betegek és szüleik gyakran nem tudnak beszámolni a pontos elözményekről és az arteficiális dermatitis szempontjából lényeges anamnesztikus adatokról 
(6). A diagnózis megerősítéséhez elengedhetetlen a részletes anamnézisfelvétel, a gondos fizikális vizsgálat (dermatoszkóppal is) és az egyéb lehetséges kórképek kizárása. Ezek többek közt: infekciók, kontakt ekcéma, vasculitis, panniculitis, tumorok, autoimmun hólyagos betegségek és pyoderma gangraenosum. Továbbá kábítószer-abúzus és elsősorban gyermekek, serdülők esetében fizikai és szexuális bántalmazás, illetve pszichoterror lehetősége is felmerülhet (4). Ahogy a mi esetünkben is látható, a differenciáldiagnosztika során nagy segítséget nyújthat továbbá a dermatoszkópos vizsgálat.

Van néhány olyan általános klinikai jellegzetesség, ami felhívhatja a figyelmet az önsértő magatartás lehetőségére. A bőrelváltozások jellemzően a beteg által könnyen elérhető területen találhatók, jobbkezeseknél például elsősorban a bal testfélen (7). Egy retrospektív tanulmány 201 arteficiális dermatitissel diagnosztizált beteget vizsgált, a résztvevők közt 44 gyermek (átlagéletkor: 12,9 év) és 157 felnőtt volt (6). Fiatalok esetében a különféle bőrelváltozások gyakorisága az alábbiak szerint alakult: exkoriáció $(36,4 \%)$, fekélyek $(22,7 \%)$, hólyagok $(15,9 \%)$, égési sérülés $(6,8 \%)$, kontaktdermatitis $(6,8 \%)$, haematoma $(4,5 \%)$, panniculitis $(2,3 \%)$, cheilitis $(2,3 \%)$ és hiperpigmentáció (2,3\%). Az elváltozások leggyakrabban az arc és nyak területére lokalizálódtak, ezen kívül a combon, lábszáron, mellkason és hason is előforudlt önsértés. Felnőtteknél szintén az exkoriációk (29,9\%) és a fekélyek $(26,1 \%)$ voltak a leggyakoribb bőrtünetek. Onycholysis csak felnőtteknél fordult elö (6). Más szerzők beszámoltak olyan esetről is, ahol azonos lokalizációban mutatkozott egyszerre arteficiális dermatitis és trichotillománia (8). A morfológiai jellegzetességeken kívül további segítséget nyújthat az esetleges idegen testek, idegen anyagok jelenléte a bőrelváltozás területén. Ennek megfelelően szövettani és mikrobiológiai vizsgálat is segítheti a diagnózis tisztázását (6). A klinikum gyakran krónikus-recidiváló lefolyást mutat, ám gyermekeknél, súlyosabb pszichopatológiai háttér hiányában a betegség idővel jelentős javulást mutat, így náluk a prognózis kedvezőbb, mint felnőttek esetén (6).

A terápia során a börtünetek ellátása mellett fontos a betegek pszichés vezetése is. A diagnózis tapintatos közléséhez, a megfelelő compliance kialakításához és a terápia sikeréhez elengedhetetlen egy elfogadó, bizalmas orvos-beteg kapcsolat kialakítása. A beteg családjával való kommunikációra szintén figyelmet kell fordítani, különös tekintettel a kórképről való részletes felvilágosításra. Utóbbi gyakran nehézségekbe ütközik, ugyanis sokan nem hajlandóak elfogadni magyarázatként egy pszichiátriai probléma lehetőségét és ennek megfelelően a pszichiátriai kezelést is visszautasítják. Ilyenkor az is előfordulhat, hogy inkább felkeresnek egy másik orvost, ami a kezelés megkezdésének további halasztásához vezet. A bőrtünetek ellátása során fedőkötés és szükség esetén lokális sebkezelés alkalmazandó, indokolt esetben akár osztályos felvétellel. A további terápiáról az alapprobléma ismeretében lehet dönteni. Szükségessé válhat antidepresszáns vagy antipszichotikum beállítása (9). Adott esetben szedatívumok is segíthetnek, az opiátokat azonban tanácsos kerülni az egyébként is vulnerábilis betegeknél egy esetleges függőség kialakulása miatt (9), (10). Sokszor a betegek sérült önértékelése és önbizalma vezet önkárosító magatartáshoz, melyen kognitív viselkedésterápia segíthet (11).

Pszichiátriai betegségek közül többek közt személyiségzavarokhoz, depresszióhoz és az impulzuskontroll zavaraihoz gyakran társul arteficiális dermatitis (10). Poszttraumás stressz zavar is állhat a háttérben, pl. közeli hozzátartozó elvesztése, súlyos baleset vagy nemi erőszak után. Traumák után előforduló disszociatív zavarral való összefüggést is kimutattak, mely során a betegek feszültségüket önsértő magatartás formájában próbálják levezetni (12). Fontos kiemelni, hogy különösen fiatal betegeknél az öngyilkossági rizikó is magasabb (13).

Ahogyan a mi esetünkben is látható, gyermekeknél és serdülökorúaknál elfojtott félelem vagy tekintélyszemélyekkel (szülők, tanárok) való feloldatlan konfliktus kapcsán kialakuló maladaptív megküzdési folyamatok is vezethetnek arteficiális dermatitis kialakulásához, de gyakori kiváltó ok a szülők általi érzelmi elhanyagolás is (10). Az irodalmi adatok alapján arteficiális dermatitis társulhat még figyelemhiányos hiperaktivitás-zavarhoz is (14).

A szerteágazó pszichés és pszichiátriai vonatkozások miatt a diagnózishoz és a megfelelő terápiához elengedhetetlen ezen esetlegesen társuló zavarok felderítése. Az utóbbi időben előtérbe kerülő teledermatológia kapcsán szükséges megemlíteni az ezzel kapcsolatos kihívásokat is. Az ellátás jellege miatt nincs lehetőség alapos explorációra, így részletes anamnézis és célzott kérdések hiányában még könnyebben elmarad az arteficiális dermatitis felismerése. Bizarr, másképp nehezen magyarázható bőrtünetek esetén azonban a teledermatológiai ellátás során is gondolni kell az önsértés lehetőségére és a kivizsgálást személyes konzultáció keretében szükséges folytatni.

Összegzésként elmondható, hogy az arteficiális dermatitis egy interdiszciplináris probléma, melynek felismerése sok esetben nehézséget okoz és előfordul, hogy a betegek számos orvosnál megfordulnak, mire tisztázódik a diagnózis. Bizarr, szokatlan megjelenésü bőrtünetek esetén az arteficiális dermatitisnek szerepelnie kell a differenciáldiagnosztikában. A sikeres kezeléshez pszichodermatológiai szemlélet és megfelelő szakemberek közös munkája szükséges.

\section{IRODALOM}

1. Rodríguez Pichardo A, García Bravo B.: Dermatitis artefacta: a review. Actas Dermosifiliogr. (2013) 104(10), 854-866.

2. Gattu S, Rashid RM.: Khachemoune A. Self-induced skin lesions: a review of dermatitis artefacta. Cutis. (2009) 84(5), 247-251.

3. Lavery MJ, Stull C, McCaw I. és mtsai.: Dermatitis artefacta. Clin Dermatol (2018) 36(6), 719-722. 
4. Tittelbach J, Peckruhn M, Elsner P.: Histopathological patterns in dermatitis artefacta. J Dtsch Dermatol Ges (2018) 16(5), 559564.

5. Gutierrez D, Schowalter MK, Piliang MP. és mtsai.: Epidermal multinucleated keratinocytes: a histopathologic clue to dermatitis artefacta. J Cutan Pathol (2016) 43(10), 880-883.

6. Alcántara Luna S, García Bravo B, Rodríguez Pichardo A. és mtsai.: Dermatitis Artefacta in Childhood: A Retrospective Analysis of 44 Patients, 1976-2006. Pediatr Dermatol. (2015) 32(5), 604-608.

7. Ferri JVV, de Araujo DB.: Dermatitis artefacta mimicking cutaneous vasculitis: case report and literature overview. Reumatologia. (2019) 57(2), 106-108.

8. Sarin A, Ummar SA, Ambooken B, Gawai SR.: Dermatitis Artefacta Presenting with Localized Alopecia of Right Eyebrow and Scalp. Int J Trichology. (2016) 8(1), 26-28.
9. Mohandas P, Bewley A, Taylor R.: Dermatitis artefacta and artefactual skin disease: the need for a psychodermatology multidisciplinary team to treat a difficult condition. Br J Dermatol (2013) 169(3), 600-606.

10. Chandran V, Kurien G.: Dermatitis Artefacta. In: StatPearls. Treasure Island (FL): StatPearls Publishing; 2020. Közlés alatt.

11. Chung WL, Ng SS, Koh MJ. és mtsai.: A review of patients managed at a combined psychodermatology clinic: a Singapore experience. Singapore Med J (2012) 53(12), 789-793.

12. Gupta MA, Jarosz P, Gupta AK.: Posttraumatic stress disorder (PTSD) and the dermatology patient. Clin Dermatol. (2017) 35(3), 260-266.

13. Al Hawsawi K, Pope E.: Pediatric psychocutaneous disorders: a review of primary psychiatric disorders with dermatologic manifestations. Am J Clin Dermatol. (2011) 12(4), 247-257.

14. Patra S, Sirka CS.: Attention deficit hyperactivity disorder presenting as dermatitis artefacta. J Pediatr Neurosci. (2016) 11(1), 80-82.

Érkezett: 2020.06.23.

Közlésre elfogadva: 2020.06.30. 